\title{
Parliamentary Immunity in International Legislation
}

\author{
Amal Yusuf Alrfua ${ }^{1}$, Ahmad Hasan Abu Sabah $^{1} \&$ Ayman Yousef Mutlaq Alrfoua ${ }^{2}$ \\ ${ }^{1}$ Department of Comparative Law, Sheikh Nooh Alqudah's Faculty of Sharia and Law, International University \\ of Islamic Sciences, Jordan \\ ${ }^{2}$ Department of Law, Middle East University, Jordan \\ Correspondence: Amal Yusuf Alrfua. E-mail: amalrfoua@yahoo.com
}

Received: March 25, 2018

Accepted: April 2, $2018 \quad$ Online Published: May 28, 2018

doi:10.5539/ass.v14n6p71

URL: https://doi.org/10.5539/ass.v14n6p71

\begin{abstract}
A Legislature is one of the most important bodies in a country, because in addition to its primary duty of passing legislations it also monitors the executive body and holds it accountable for the execution of its duties. Due to this responsibility the national legal systems have granted legal protection for members of the legislature to aid them to carry out their assigned responsibilities in accordance with the constitution, this protection is known as Parliamentary immunity.

We have clarified the concept of Parliamentary immunity and its legal nature, in addition we have also discussed its types (objective and procedural) and made clear the differences between them. In addition, we pointed out the procedure of lifting the immunity, legal reasons that require it be lifted and the position of some constitutions in regard it.

We have also explained and indicated whether Parliamentary immunity was successful in protecting the legislature from intimidation or strong-arming of the executive authority.

\section{Introduction}

Throughout history parliaments have been recognised as the voice of people since the main purpose of it is to represent the entirety of the nation in any given country. And the role of a member of parliament does not constrict to only representing people in their province but has greater role in representing the entire nation. Constitutions have assigned the parliament its duties of watching over the government's activities and passing legislations for the country, and due to the development and evolution of the parliament over recent years, a balance between the legislative and executive authorities was created in which both could practice their constitutional duties. Parliamentary immunity has been the main tool which led to the creation of this balance which allowed the members of parliament and the senate to scrutinize decisions made by the government and voice the will of the people they represent without pressures or threats of legal actions or questioning by the executive government. This right has been guaranteed to members of the legislature by constitutions all over the world to ensure that those members cannot face malicious legal pressures set to strong-arm them into submission by any party and provides them with the freedom of expression and freedom of choice. Parliamentary immunity does not at all mean that a member of the legislature is above the law but is merely a tool to protect them while they serve their constitutional duties.
\end{abstract}

Based on this argument, the researcher will discuss the following topics:

1. The legal nature and concept of parliamentary immunity:

a. What is parliamentary immunity?

i. Conceptual and linguistic meaning of immunity.

ii. Typed of immunity.

b. Legal nature of parliamentary immunity.

2. Forms and justifications of parliamentary immunity:

a. Forms of parliamentary immunity.

b. Justifications for parliamentary immunity. 
3. Procedure for lifting immunity and reasons for its termination.

a. Procedures for lifting parliamentary immunity.

b. Reasons for its termination.

\subsection{Significance of the Study}

This study has shed light on the justifications of parliamentary immunity and its legal implications which help protect members of the legislature from intimidation and malicious legal prosecution by the executive government. This study also looked into reasons why such immunity might be revoked, and also acted as feedback to experts in the fields of parliament and constitution and member of the parliament and the senate. The study also considered to weigh legal strengths and weaknesses of the immunity to create a general perception to provide decision makers in the parliament and the legislative bureau with relevant feedback.

\subsection{Research Problems}

Through observation of parliamentary councils during their terms and the times of their dissolution and through the experience of the principal researcher as a member of the Jordanian parliament and feared she had observed from other members about requests from some parties asking the chairman of the council for the revocation of the immunity of some members of the parliament. She had also noticed some problems that have picked up tractions among ordinary people and law specialists about the lifting of immunity from this member or that member. Instances like this have been repeated though the revocation of immunities from some members so that they may stand trial for a criminal offence. Due to multiple points of view about what parliamentary immunity actually is and what occurrences justify its revocation, it was necessary to have a study discusses reasoning behind revoking or keeping the immunity instated in light of the offences the member of parliament might have committed, and so parliamentary immunity which constitutions have guaranteed, is only to protect freedom of opinion and expression and the freedom to practice their duties with complete independence and without fear of being intimidated by the executive government. Thus, the following questions were answered in this study:

1. What is the concept of parliamentary immunity and what is its legal status?

2. What are the forms and justifications of parliamentary immunity?

3. What are the procedures of lifting this immunity?

4. What are the cases leading to termination of parliamentary immunity and what are the effects of it?

\subsection{Aims of the Study}

This study aimed to identify parliamentary immunity and its legal status and to identify reason leading to the revocation of such immunity and its effects. Toward achieving this aim, three topics were discussed in this study:

\section{The Concept of Parliamentary Immunity and Its Legal Nature}

\subsection{Conceptual and Linguistic Meaning of Immunity}

Definition of Immunity in the Arabic language: Chastity, protection, resistance, and Allah has said in his holy book: AAnd We taught him the fashioning of coats of armour to protect you from your [enemy in] battle. So, will you then be grateful?\} Al-Anbiaa Sura, [verse 80]. Allah also said: \{This day [all] good foods have been made lawful, and the food of those who were given the Scripture is lawful for you and your food is lawful for them. And [lawful in marriage are] chaste women from among the believers and chaste women from among those who were given the Scripture before you, when you have given them their due compensation, desiring chastity, not unlawful sexual intercourse or taking [secret] lovers. And whoever denies the faith - his work has become worthless, and he, in the Hereafter, will be among the losers.\} Al-Maeda Sura, [verse 5].

Definition of Immunity as a term: It was essentially a privilege decided by the international law or internal law of a country which relieves a person of a burden that has been imposed on the people of the nation in general or grants him/her the privilege of not being prosecuted by the legal authorities.

The historical foundation of Parliamentary immunity return back to the year 1397 when the House of Commons in the Parliament to the United Kingdom voted on a law which condemns the behaviour of the King Ritchard the second which consequently led prosecuting Thomas Haksy (the member in the Parliament) who took the lead in this issue with execution for his betrayal. After this, a Royal pardon was released after arguments by some groups which took to the House of Commons to discuss the rights of members of this house to talk freely without being interrupted by the royal court. This also recognised the right of the Parliament members to express in the $16^{\text {th }}$ century and confirmed it in the $18^{\text {th }}$ century through the rights law in 1689 . This agreement dictated that the right to talk, discuss, and do inside the Parliament will not be a reason for legal prosecutions in any of 
legal courts. However, issues related to major betrayal, crimes, and disturbing security were all exempted from this immunity, so it was possible to attest any of the parliament members in any of these crimes with being disclosed from immunity (Hussainyeh, p. 151).

\section{Types of Immunity}

Parliamentary immunity is split into two categories:

\section{Substantive immunity}

\section{Procedural immunity}

And what can be meant by substantive immunity is a member of parliament cannot be held liable for his opinions and suggestions inside the parliament. However Procedural immunity means that no legal action can be taken against the member by any party or citizen while they are within their parliamentary term unless permission is given by the parliamentary council, except in the case they commit an offence against another member during the parliamentary term (Altugeeri, 2009, p. 17).

In the opinion of some jurists (Kashkash, 2007, p. 40) Procedural immunity is a constitutional privilege given to a member of parliament not for their person but for being a person representing the people so that they may practice their duties to the best of their ability. Although this immunity is a constitutional guarantee though it does not pardon them from offences they commit, these crimes are postponed unless they caught in blazing offence.

Immunity was also considered as protection for a member of parliament against allegations of penal and civil offences, and against being interrogated (Jain, 1984, p. 6). And based on what has been mentioned, it was apparent that main purpose of parliamentary immunity was to ensure that a member of parliament is not abruptly removed from the council during their term unless it has become very clear to the parliamentary council that an offence has actually been committed and is not a malicious allegation whose purpose is to stop a member from preforming their duties as representatives, and this alone limits parliamentary immunity (Mustafa, 1984, p. 384). And concerning the Substantive immunity, it was described as a permanent immunity regarding anything said by the member of parliament or ideas they have presented and cannot be questioned in their regard even after the member's term has ended. With procedural immunity however, it was only a matter of postponing action, and so we noticed that there was no effect on the legislations made by a member who commits an offence. And in the case of being caught in blazing offence, the member was detained without needing to inform the council to which they belong. But there are instances; in the French law for example, where the member is detained following an offence while withholding legal actions until the council agrees to allow them to commence, and before the council's term commences officially anyone can pursue legal matters concerning the members.

Also, there is a difference in the extent of implementing immunity on different types of offences. In some cases, its extent included crimes and misdemeanours where as in some constitutions it included crimes, offences and misdemeanours as what was seen in the Egyptian legislations.

\subsection{Legal Nature of Immunity}

In order to preserve the independence of the legislative authority, so it may carry out its duties with freedoms that its members need in order to do so, they must be protected from any threats or malicious lawsuits/allegations that may interfere with their ability to perform their duties. And so, the immunity can provide protection for the member of parliament because their job dictates it necessary, and not because of their person. For these purposes immunity was considered as an important component of the constitution because it regulated the relationship between different government bodies and because it gave the member of parliament the freedom to express opinions without questioning so he may fulfil the people's will that got him into the parliament. And so the immunity of the members of parliament, be it against parliamentary liability or against legal actions (Alaazmi, 2011, p. 28) was only a tool to provide freedom of speech and expression and as many jurists have described it as being a procedural platform to delay legal actions and law suits with permission from the council during his/her parliamentary term, and that the immunity was in no way a pardon from offences, crimes or responsibilities the member may have committed or have.

Parliamentary immunity was considered a part of the general political system, and that creates consequential conditions (Alaazmi, 2011, p. 28):

1. A member of parliament does not have the option to remove their own immunity under any condition

2. If a case is sent to courts before a parliamentary term is over, it is compulsory for the court to reject it as it defies the legal protocol, and the court makes this ruling automatically even if the member does not invoke the 
use of the immunity specifically.

3. Any legal criminal procedures taken against a member of parliament without the permission of the council or its chairman, except in the case of being caught in blaze offence, is considered null.

4. It is permitted to invoke the use of immunity, regardless of the stage the lawsuit is in, even for the first time in the courts for resumption or revocation.

Some may consider Parliamentary immunity a way for the members to bypass the constitution which states that every citizen is equal, because from their point of view they consider it to be a way out from punishment and so they might use it to break the law, abuse their position for personal gain or to commit criminal activity unquestioned (Shurun, p. 153).

Other opinions suggested that it was not for purposes of protection within the parliament but protection from prosecution while on their parliamentary term (Shurun, p. 153).

But in general, immunity was considered a principle which has been agreed on by the majority of constitutions worldwide despite differences in political and/or legal systems because it is considered a protection for the independence of their role and not their person (Saleh \& Tamah, 2011, p. 94).

Parliament was formed to represent the people and so it must be concerned with anything that concerned the people, and so must try to defend and negotiate in all matters on their behalf.

And so, the predominant opinion suggests that parliamentary immunity does not tip the scales in anyone's favour in terms of equality between citizens, because equality is applicable to people within a group who are of the same status and circumstances. Since the parliament can be seen as a different group with circumstances, and so immunity was only granted to them because of the conditions brought upon them by the nature of their duties, which consist of defending peoples' interests, and questioning government's decisions. This makes immunity a transitionary and protective necessity leaving any interferences from other government parties in their duties at bay (Al-Qaisi, 2011, p. 13). And from what we have seen there were many different opinions, where some believed that immunity was a tool to shield the member from facing trial from their crimes and contaminates the concept of equality, and some argued that not all elected councils have immunity for their members and the concept of immunity does not affect the principle of equality because it is as one might say a job related privilege within the frame of parliamentary work, and here it was clarified that this privilege was not simply for the person but a protection of their role as a member of parliament so that they may carry out their duties without fear of other political or governmental parties.

\section{Forms and Justifications of Parliamentary Immunity}

\subsection{Forms of Parliamentary Immunity}

Parliamentary immunity was derived from the principle that the nation's people are the source of its authority, and parliamentarians were merely representatives of those people, and so when a member of parliament raises an issue or voices an opinion they are only echoing the voice of the people. The idea of immunity was introduced in England in the $17^{\text {th }}$ century, where immunity was a privilege given for the common good and in favour of individuals (Alaazmi, 2011, p. 16).

Parliamentary immunity was called a parliamentary privilege in the U.K. and there were two main functions of it, the first being freedom of speech or silence, and the other was the ability challenge the crown (Bomdian, 2015, p. 18).

And so subsequently we can deduce that a parliamentary immunity does not mean that any crime committed by the member holding it becomes legal or protected, but that the immunity was only a delayer of inevitable events, and so any legal questioning or procedures are to be carried out after the immunity has lived its course unless permission was obtained by the respective council or the fulfilment of certain conditions. But when we look at substantive immunity we see that it does not have an expiry date, and so the protection of the members right of opinion remains even after their term has concluded (Fawzi, 1994).

And so we can consider it to be a guarantee against arbitrary commencement of legal actions against the member of parliament that could be malicious or a way to settle scores, and this all because the member may be opposed in opinion on the government's policies or because the member places a governmental sector under scrutiny which is considered to be a right of the member (Alshawabkah, 1997, p. 28). And so, the parliamentary immunity was split into two types:

\section{Objective parliamentary immunity.}




\section{Procedural immunity.}

\subsubsection{Objective Parliamentary Immunity}

Objective parliamentary immunity means that a member of Parliament Cannot be prosecuted in a criminal or civil Court at any time about any opinion or ideas they put forward in the house of Parliament (Al-Qaisi, 2011, p. 10; Murad, 2015, p. 23).

This means that the Member of Parliament can speak freely within the authorities that they have been granted and is able to present any ideas all opinions without any fear and that is, so they can perform their duties to the best of their abilities (Al-Jamal, 1995).

Objective Parliamentary immunity is not absolute, but as in fact limited by two important factors (Alaazmi, 2011, p. 23):

a. Opinions that a member may present during the serving of their term, during a legislative session, and when they vote for or against legislations, in accordance with their belief on the matter, or when inquests are directed at any member of government.

b. Ideas and opinions the member expresses outside parliament but are related to their duties or opinions that they may express through their membership of different committees in the council.

\section{Properties of Objective immunity:}

Objective immunity has a number of a unique characteristics and features that we specify as follows (Murad, 2015):

a. Complete immunity: it covers all speeches, opinions and everything the member says under the umbrella of their duties.

b. Permanent immunity: This protects the member of parliament while they are serving their term and after it ends, and so the member benefits from this even if they are not re-elected, and this is under the condition that the protected opinions were said during the period of immunity.

c. Absolute immunity: Includes objective immunity, which protects the member from criminal, civil and political liability, and so the public prosecutors' office cannot initiate any legal file regarding those areas, and the affected party cannot demand any sort of civil compensation and the political authorities cannot in any way prosecute them.

d. It is a part of the general regulations/law: this means that the member cannot refuse or revoke their own immunity and a judge must take it into account automatically, and it can be invoked at any stage of the lawsuit.

\subsubsection{Procedural Immunity}

This refers to the prohibition of legal procedures to be initiated against the member of parliament about a crime until the permission is granted from the parliamentary council (Murad, 2015, p. 25). This what the article (1/86) from the Jordanian constitution and its amendments dictated and said "A member of both the Senate or the Parliament will never been detained or prosecuted during the meeting unless a decision by the vast majority to say that there is a justified reason to do so or if s/he is detained while in a criminal offense and even though the council should be informed immediately". This text has been interpreted by the Jordan constitutional court in its decision 7/2013 when it said that "The court considers that, a part of the two situations mentioned before, the member should not be detained or prosecuted during the meeting for criminal acts whether before or after being a member until he is lift of the immunity which should be agreed by the vast majority of the Senate or the Parliament to which he belongs.

This might indicate that the constitutional court has widened the boundaries of the Parliament immunity to include all criminal acts which may be performed by the member either before or after being a member.

The Palestinian constitutional court has granted the right for the president to lift any member in the legislative council of the immunity without the council being held in the interpretative decision 3/2016 which dictates that "The high constitutional court consider the decision 4/2012 taken in 3/1/2012 which implied lift of immunity for the legislative council member Mohammad Yousef Shaker Dahlan, who has been contested in the court in a criminal case (decision cancelled 326/2915 which has been made appropriately and according to the rights granted to the president in the law "Decision of the Palestinian high constitutional court 3/2016)".

And the procedural parliamentary immunity consists of the principle of physical freedom, as they could be physically detained and so won't be able to vote in favour or against certain issues, and this prosecution may 
have nothing to do with parliamentary affairs, because anything within the parliament is protected by the objective immunity, and the points that follow may be seen as points of difference between the two types of immunity (Alaazmi, 2011, p. 25).

And based on that we see that procedural immunity is only a matter of delaying action until the immunity is lifter by the council except in cases of flagrante delicto.

\section{Properties of Procedural Immunity}

Procedural immunity has a number of a unique characteristics and features that we specify as follows (Murad, 2015):

a. It is temporary in nature and not permanent like the objective immunity, and only lasts through the period of the members term, in addition some constitution stated that procedural immunity also ends at the end of the parliamentary term, examples are the Jordanian and the Lebanese constitutions.

b. It is a part of the general system that has been stated in the constitution and cannot be overruled, and so any legal procedure is considered void against a member of parliament. The criminal chamber in cassation court has approved with the invalidation of the procedures that were performed and broke down the immunity principles (See the decision of the criminal chamber of the cassation court dated 5/8/1985.

c. This immunity is not like the absolute immunity and so any person affected by a member's actions can take it to civil court.

d. A member cannot lift this immunity except by submitting a formal request to the respective council chairman as per the law.

The fundamental difference between objective and procedural immunity is that it includes parliamentary members from the present and the past since the effects of opinions may extend till today and the member can't be prosecuted for the people's opinions, whereas only present members can benefit from procedural immunity, so it may not cover criminal or illegal activity the member may commit (Murad, 2015, pp. 28-29).

\subsection{Justifications for Parliamentary Immunity}

There were a few justifications for parliamentary immunity, these justifications allow the Member of Parliament to carry out their duties while being guaranteed absolute freedom of opinion and expression. It also allows the Member of Parliament to represent the people correctly as he has the freedom to speak and to criticize the government without fear, and so objective parliamentary immunity ensures that the Member of Parliament is not questioned about anything that they express during their time as a parliamentarian. And this guarantee extends from the time they are elected and after the end of their term.

Most constitutions around the world Granted immunity to members of parliament as a guarantee that they can practice their duties with absolute freedom and Boldness. And because confidence and Independence were the pillars of the duties of a parliamentarian, so that they do not fall under pressure or be used by the executive Authority. Immunity was instated to guarantee the Member of Parliament the right to his opinion without fear. This immunity does not aim but to stop the executive government from fabricating lawsuits to stop a member from voting or to change their stance forcibly about a certain matter, and this immunity was not given to the member because of their person but as a way to allow them to practice the job (Shawabkah, 1997, p. 14). And so we found that this immunity has legal effects that can be seen in the passage that follows (Azmi, 2011, pp. 77-78).

\section{Consequential effects of parliamentary Immunity}

1. Ideas and opinions cannot be placed under a criminal domain, if it does not cross the boundaries of the law, and so a member of parliament cannot be asked for compensation for damages.

2. The effect dog objective immunity for a member of parliament stretches even after the end of their term, and compensation regarding matters under the umbrella of this immunity are not allowed.

3. A member of parliament is still required to remain within responsible and decency that the law has stated. The immunity does not pardon the member for breaking internal laws of the council or allow them to use the immunity where they cannot, because this would mean they are acting outside the agreed upon rules of the parliament.

4. It is a right for a member of parliament to refuse to waiver the immunity and if they do not state it then the judge must make it so automatically on their behalf.

5. The only beneficiary from the immunity is the person who has acquired the right to be a member of the 
parliament and no one else can benefit from it.

\section{Procedure for Lifting Immunity and Reasons for Its Termination}

It has been stated in many constitutions that a member of parliament must not be detained or stand trial during their parliamentary term, except if the parliamentary council decision otherwise on which the council must pass the decision with a majority vote for a serious enough offence. The immunity may also be disregarded or lifted if the member is caught in blazing offence.

\subsection{Procedures for Lifting Parliamentary Immunity}

If a member of parliament commits a crime during their parliamentary term, the Prime Minister proceeds to tell the chairman of the council to which that member belongs to take necessary action and sends a detailed explanation of the crime, and this is what most constitutions dictate happens in such circumstance. No public prosecutor can take any actions until after permission has been granted from the chairman of the council the member belongs to Kashakesh (1997 pp. 45-46). So consequentially the order for the revocation of the immunity was presented in accordance with the regulations of the council; This is because immunity delays any prosecutory action until permission is granted by the council. At this point the council's duty was to ensure whether the crime has actually been committed or was just a malicious accusation, and if it was determined that the crime was committed by the member then the order to revoke their immunity is effective and all criminal legal action is taken against the member (Murad, 2015, pp. 84-85; Kashakesh, 1997, pp. 45-46).

And so it is made clear that the process of revoking the immunity begins with an official Request from the chairman of the council to which the member belongs, and when a parliamentary council meeting is held, this request is processed and a verdict is made based on the evidence presented, on whether to revoke the immunity or not, and if the council does not give a verdict within the designated 2 months this can be considered a permission to lift the immunity as has been mentioned in the Algerian Constitution. And in case the council does not hold a meeting, the council is then informed of any procedures taken against that member.

\subsection{Reasons for Its Termination}

Objective immunity begins and continues onwards from the day the member is elected and does not end under any circumstance for it protects the ideas and opinions of the member because they represent the guarantee of independence for the legislative authority. And this immunity is subject to a few regulations, the system of work and the member's duties.

Procedural immunity however: the law decides the cases that this immunity is terminated, in accordance with scope it resides under (Alshawabkah, 1997).

There were more than one way to terminate a parliamentary immunity:

1. Civil lawsuits: in some countries a civil lawsuit is a valid reason for the immunity to be lifted and so anyone can make a lawsuit against a member of parliament at any time and ask for compensation. The immunity does not necessarily mean member protection from being prosecuted in civil and commercial with the aim for those Lawsuit was to have civil compensation and this was has been approved by the French Judicial court which said that "This solution was offered so the Parliament responsibility for the member does is not a reason for him to be arrested neither to apply a physical harm upon him". (Decision of criminal chamber for the French Court of cassation (1893).

2. Being caught in blazing offence (red-handed): In most constitutions caught red handed in a crime is excluded from the immunity's reach and so if it occurs the immunity is therefore removed, article (41) from the French rules of trial procedures. And this case also includes when a crime or offence is done publicly, or when a person is found holding items tying them to a crime or having papers announcing their involvement in a crime, under the condition that this happened at a time close to that of the occurrence of the crime; as seen in article (28) of the Jordanian criminal trial procedures: a witnessed crime is a crime in which the perpetrators are detained in the middle of a local outrage at the crime scene, or are caught with weapons, items, papers that can prove their involvement in the crime within 24 hours of the crime. It is only normal for the immunity to be revoked in cases of blazing offences because the parliamentary immunity is not a means to cover crimes up but was introduced to aid the interests of the people. And it has become apparent that in blazing offences are not protected by any immunity in any constitution in any way.

3. Reaching the end of a parliamentary term normally:

The parliament comes to comes to an end differently in each country depending in the duration of the length of the parliamentary course as stated by their constitution, for example in Jordan the term ends after 4 years from 
the date of election, whereas in France the term is 5 years long. The ending of the parliamentary term also means the immediate withdrawal of any privileges that come with it, and so they can no longer be responsible for holding the government accountable for its actions, they no longer have the duties associated with members of parliament, and they are no longer out of reach of civil courts (Alshawabkah, 1997).

4. Dissolution of the parliamentary council:

This is a weapon in the hands of the executive government that they use against the parliament, and so when a royal or presidential decree is passed down by the king or president the immunity ends, and any members can be taken to courts as normal with the need of approval from the council.

And what is meant by dissolution of the council is: the end of a parliamentary term before it has run its full duration, and it has been stated in many constitutions including the British and Jordanian, that the power to dissolute a council is in the hands of the king/queen and in other countries the president with a few restrictions. For example: in Jordan the dissolution of the parliament also means the dissolution of the government processed the request of dissolution within one week as per the latest constitutional amendments (Jordanian Constitution, article 66).

5. Death of the member:

Immunity is a constitutional privilege that is given to a person and so if the person is deceased they are no longer an MP, and so the immunity is stripped with the status.

6. Loss of competence:

Meaning of competence: fitness of a person to have rights and responsibility (Murad, 2015) and the loss of any accountability due to medical conditions such as dementia, madness etc. And this means that the member has lost competence and accountability and, in some cases, partially.

7. Resignation:

This means that a member of parliament must by their own will submit a request to terminate their services in the council, and it is considered effective when the chairman accepts their resignation and so the immunity is then lifted automatically; this is in accordance with internal regulations of the Jordanian parliamentary council, article $(157,158,159)$ (Murad, 2015).

8. Impugning the legitimacy of a member's election:

Impugning the election results after they have been calculated due to ill practices, forgery, disputes over formalities in the process (Qaddourah, 2009).

\section{Caught in blazing offence:}

Article (26) of the French constitution and article (96) of the Jordanian constitution; and what we mean here is the witnessed crime as per the Jordanian criminal system article (28), revoke the immunity of a member because it is in blazing offence and cannot be delayed. And this is because it is necessary to uphold equality between citizens. And so, an arrest is the main reason for limiting the members' freedom.

\section{A member's waiver of their immunity:}

Many constitutions, including the Jordanian constitution, have agreed that it is not permitted for a member to waiver their immunity without permission from their respective council, because it is considered to be a right and it is not in the members favour to forfeit any of their rights.

Therefore, a member is obliged to follow the council's orders, and the waiver of the immunity must provide a clear, precise reasoning, because the waiver is temporary and does not last till the end of the term.

It has become clear from the previous list of ways above that the normal and abnormal termination of the immunity all are dependent on the specific term the person is a member. The Egyptian constitution goes to say that the immunity lasts the same period as the parliamentary term, whereas the Jordanian constitution it is constricted to the end of the traditional, non-traditional, and exceptional parliamentary cycle. This means that the immunity ends with the end of the parliamentary cycle, or after the duration of the term or until its dissolution, and there are many different opinions between jurists about this matter.

\section{Conclusions}

As we have made clear before, parliamentary immunity is the most important guarantee, so the member of parliament can carry out their duty freely and in accordance with the constitution, by criticizing the government, directing questions and inquiries and all the tools that can be used to supervise government decisions. And the 
immunity provides a safe shield against threats and intimidation by the executive government. And the researcher has come to the following conclusions:

1. Constitution is the binding legal document that regulates the relationship between different authorities in the government.

2. Parliamentary immunity is the most importance guarantee of protection for the member of parliament.

3. Some call immunity an unconstitutional privilege because it distorts the concept of equality.

4. There are differences in how different constitutions define immunity.

5. Objective immunity is absolute, and what is meant here is in relation to the unrestricted freedom to ideas, opinions and speech in the house of parliament.

6. Parliamentary immunity is a constitutional element and has acquired its validity from constitutions around the globe.

7. Parliamentary immunity is for the common good and not personal gain.

8. Immunity does not cover in blazing offence nor witnessed crimes.

9. Different country's political systems decide specific details regarding immunity.

The procedural immunity has been made specific to actions that have no relation to the parliament and are under the umbrella of criminal offences, and so it is not possible to sue a member of parliament without the permission of the parliamentary council, and after the immunity is lifted in accordance with the internal council regulations.

Members are given special privileges, because they do not represent themselves when speaking or expressing opinions but are in fact representing the entire nation. And so, the immunity is nothing but an aiding tool for the common good of the people, by providing the member independence. Even though immunity has been criticized as being unconstitutional, and goes against the concept of equality in punishment, it has also been defending by some because it does not belong to the person in question but their role as a member of parliament.

\section{Recommendations}

1. It should be stated in the constitution that immunity extends beyond the parliamentary term, so a member is not maliciously sued after the end of the term.

2. Immunity should not be lifted during periods when sessions are not held.

3. There should be legal specialists to decide in cases of revoking an immunity because they possess more knowledge of legal matters that the council.

4. Immunity has become a constitutional principle in many countries around the world and has become a source of protection for the member, therefore the executional government should get less of a say on matters such as immunity and less influence on matters such as the dissolution of the parliamentary council.

5. The should exist a set of procedures to strengthen parliamentary immunity. This means that members' opinions would be reinforced within the context of objective immunity.

6. Immunity within Islamic jurisprudence so regulations and limitations may be set in accordance.

\section{References}

Alaazmi, M. M. (2011). Parliamentary immunity a comparison between Jordan and Kuwait (Unpublished Master's Thesis). Middle East University, Jordan.

Aljamal, Y. (1995). Egyptian constitutional system (2nd ed.). Dar alnahda alarabyia, Cairo.

Al-Qaisi, H. M. (2011). A comparative study between the internal regulations of the parliamentary council and the national Kurdish council. Almuntaseriah University.

Alshawabkah, I. (1997). Parliamentary immunity: Comparative study (Master's Thesis). Amman, University of Jordan.

Altugeeri, A. bin A. (2009). Parliamentary immunity and its application on the saudi consultative council (Masters Thesis). Naif University for security sciences, Alriyad.

Bomdian, A. (2015). Parliament immunity; A comparative study (Published PhD Thesis). Abu Bakr University, Qaid, Telmsan.

Fawzi, S. (1994). The parliament: An analytical comparative study between world parliaments (1st ed.). Cairo: Alnahda Alarabyia Printing Press. 
Fawzi, S. A. (2000). A look into politicians and constitutional law (35th ed.). Cairo: Alnahda Alarabyia Printing Press.

Fihmi, M. A. Z. (1984). Egypt's constitutional system (1st ed.). Munshaat almaaref, Alexandria.

Jain, M. P. (1984). Parliamentary Privileges and the press. NM. Tripathi private Ltd, Bombay, India.

Kashakesh, K. Y. (2007). Procedural immunity a constitutional guarantee for parliamentary work. Almanarah Journal, 13(8).

Murad, M. O. (2015). Parliamentary immunity in Palestinian legislations (Unpublished Master's Thesis). Islamic University, Gaza.

Qaddourah, Z. A. (2009). Parliamentary immunity- a comparative study between Arab and foreign parliaments (Vol. 23). Mu'taa journal, for research and studies, social and human studies.

Saleh, A., \& Tamah, N. (2011). Legal system for immunity ( $\mathrm{PhD}$ thesis in general law). School of Law, Algeria University.

Shurun, H. (2010). Parliamentary immunity (5th ed.). Algeria: A published study in Almufaker Journal, School of Law and Political Sciences, Mohammad Khadr University.

Jordanian Constitution 1952 and Amendments.

Decision of interpretation of the Jordanian constitutional court No 7 year 2013, Published in Official Gazette, Vol 5222.

Decision of criminal chamber for the French Court of cassation (1893), Immunities 49.

Decision of interpretation of the high Palestinian constitutional court no 3, 2016

Decision of criminal chamber for the court of cassation (1982), Immunities 41.

\section{Copyrights}

Copyright for this article is retained by the author(s), with first publication rights granted to the journal.

This is an open-access article distributed under the terms and conditions of the Creative Commons Attribution license (http://creativecommons.org/licenses/by/4.0/). 